\title{
Italian Canadiana
}

\section{Frank Iacobucci Centre for Italian Canadian Studies Department of Italian Studies, University of Toronto}

Italian Canadiana is a journal of the Frank Iacobucci Centre for Italian Canadian Studies, formerly the Centre for Italian Canadian Studies. It was founded in cooperation with Centro Canadese Scuola e Cultura Italiana in 1984, and integrated into the Department of Italian Studies, University of Toronto, in 1988. In 1995 the Centre was named after Justice Frank Iacobucci, the first Canadian of Italian origin to be appointed to the Supreme Court of Canada. On the occasion, the Canadian Italian Develpment Association provided funding for its operation. The journal publishes articles and reviews in English, French, and Italian and is devoted to research on all aspects of the lives of Italian Canadians.

Editor: Salvatore Bancheri

Editors Emeriti: Julius A. Molinaro (1985-1999), Maddalena Kuitunen (1994-1999)

\section{Editorial Board}

Robert Buranello, Chapman University

Simone Casini, U. of T. Mississauga

Luca Codignola, Università di Genova

Diana Iuele Colilli, Laurentian University

Michael Lettieri, U. of T. Mississauga

Francesco Loriggio, Carleton University

Gabriele Niccoli, St. Jerome's University

Franco Pierno, University of Toronto

Domenico Pietropaolo, University of Toronto

Joseph Pivato, Athabasca University

Bruno Ramirez, Université de Montréal

Christine Sansalone, Laurentian University

Monica Stellin, Wilfrid Laurier University

Luca Somigli, University of Toronto
Board of Directors

of the Iacobucci Centre for

Italian Canadian Studies

University of Toronto

Salvatore Bancheri

Annemarie Castrilli

Elvira D'Ambrosio

Gregory Grande

Michael Lettieri

Mirella Pasquarelli Clivio

Domenico Pietropaolo

All subscriptions, business correspondence, enquiries concerning manuscript, book reviews, and editorial communications should be sent by e-mail (preferred) to: iacobucci.centre@utoronto.ca

or: Frank Iacobucci Centre for Italian Canadian Studies

c/ o Dept. of Italian Studies, University of Toronto

100 St. Joseph Street, Toronto, Ontario, M5S 1J4

Typeseting: Legas, 3 Wood Aster Bay, Ottawa, ON K2R 1B3 www.legaspublishing.com 


\section{New Perspectives}

\section{in Italian Canadian Writing}

Dynamics of Cultural Inheritance

Edited by

Delia De Santis

Special Issue of Italian Canadiana

Volume 34 (2020) 